\title{
Data report: middle Miocene to Pliocene planktonic foraminiferal biostratigraphy of the northern part of the Shikoku Basin, IODP Expedition 322 Site C0012
}

Hiroki Hayashi, ${ }^{2}$ Kazuki Yamashita, ${ }^{2}$ Pawan Govil, ${ }^{3}$ Yuki Idehara, ${ }^{2}$ Takayuki Tanaka, ${ }^{4}$ and Hiroshi Nishi ${ }^{4}$

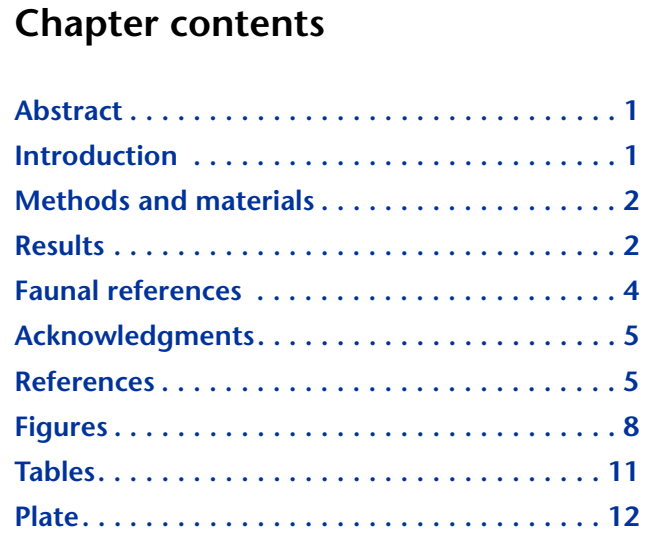

${ }^{1}$ Hayashi, H., Yamashita, K., Govil, P., Idehara, Y., Tanaka, T., and Nishi, H., 2014. Data report: middle Miocene to Pliocene planktonic foraminiferal biostratigraphy of the northern part of the Shikoku Basin, IODP Exp. 322 Site C0012. In Saito, S., Underwood, M.B., Kubo, Y., and the Expedition 322 Scientists, Proc. IODP, 322: Tokyo (Integrated Ocean Drilling Program Management International, Inc.).

doi:10.2204/iodp.proc.322.206.2014

${ }^{2}$ Interdisciplinary Graduate School of Science and Engineering, Shimane University, 1060

Nishikawatsucho, Matsue City, Shimane 690-8504, Japan. Correspondence author:

hayashi@riko.shimane-u.ac.jp

${ }^{3}$ National Centre for Antarctic and Ocean

Research, Headland Sada, Vasco-da-Gama, Pin403804 Goa, India

${ }^{4}$ Department of Earth Science, Graduate School of Science, Tohoku University, Aramaki Aoba, Sendai 980-8578, Japan

\begin{abstract}
Planktonic foraminifers collected from Site C0012 drilled during Integrated Ocean Drilling Program Expedition 322 in the northern part of the Shikoku Basin, northwestern Pacific Ocean, were examined to establish a reference biostratigraphy of the Nankai Trough Seismogenic Zone. With the exception of several barren intervals, planktonic foraminifers are present throughout the cores at the studied site. Nineteen biohorizons are recognized at the studied site. Among these, four biohorizons are refined and fifteen are newly detected after the onboard study. The studied sequence correlates with Zones M7 to PL4, ranging in age from middle Miocene to Pliocene. A new age-depth plot of the studied site is presented on the basis of foraminiferal data from this study combined with nannofossil biohorizons determined by the onboard study.
\end{abstract}

\section{Introduction}

The Nankai Trough Seismogenic Zone Experiment (NanTroSEIZE) was designed for the comprehensive understanding of the repeated mega-earthquake zone along the subduction boundary of the Philippine Sea Plate. Integrated Ocean Drilling Program (IODP) Expedition 322 is a part of the second stage of the NanTroSEIZE project. One of the main purposes of the expedition was to characterize incoming sediment and the upper igneous basement prior to their arrival at the subduction front of the Nankai Trough (see the "Expedition 322 summary" chapter [Underwood et al., 2010]). During the expedition, the R/V Chikyu drilled at Sites C0011 and C0012 in the northern part of the Shikoku Basin in the northwest Pacific Ocean. Site C0012 $\left(32^{\circ} 44.888^{\prime} \mathrm{N}\right.$, $136^{\circ} 55.024^{\prime} \mathrm{E}, 3510.7 \mathrm{~m}$ water depth) is located near the crest of a prominent basement high known as Kashinosaki Knoll (Fig. F1). At this site, ocean floor sediment and igneous basement rocks were recovered with a rotary core barrel (RCB) system from 60537.81 and 537.81-576 m coring depth below seafloor (CSF-A), respectively. The uppermost $60 \mathrm{~m}$ of sediment was jetted and therefore was not collected. The recovered sediment is mainly composed of hemipelagic claystone to siltstone with many intercalating volcanic and sand layers.

The reconstruction of the detailed deformation process of the Nankai Seismogenic Zone requires a combined stratigraphic ap- 
proach that includes biostratigraphic methods. According to results of the first stage of NanTroSEIZE, sediment from the Pliocene to late Miocene accretionary complex of the subduction zone bears calcareous microfossils including planktonic foraminifers (Ashi et al., 2009; Hayashi et al., 2011). The sediment composing the accretionary prism was originally deposited as continuous ocean-floor sediment of the Shikoku Basin. The onboard study (see the "Site C0012" chapter [Expedition 322 Scientists, 2010]) revealed that the Pliocene to middle Miocene interval of Site C0012 yields planktonic foraminiferal fossils. Therefore, this site has a good potential for establishing a standard biostratigraphy for the middle to late Miocene interval of the Nankai Seismogenic Zone. Thus, the purpose of this study is to construct a planktonic foraminiferal biostratigraphy of Site C0012 as a reference biostratigraphy for the NanTroSEIZE project.

\section{Methods and materials}

Samples used for this research were collected from Hole C0012A at an interval of 1-2 samples per core. We treated 51 samples ranging in age from middle Miocene to Pliocene. The stratigraphy of the studied site is divided into seven units; Unit I (0.0-150.86 m CSF-A) is upper Shikoku Basin deposits mainly composed of hemipelagic silty clay to silty claystone with thin interbeds of volcanic ash. Unit II (150.86$219.81 \mathrm{~m}$ CSF-A) is middle Shikoku Basin deposits consisting of silty claystone alternating with volcanic sandstone. Unit III (219.81-331.81 m CSF-A) is lower Shikoku Basin hemipelagites characterized by bioturbated silty claystone. Unit IV (331.81-418.29 m CSF-A) is lower Shikoku Basin turbidites consisting of alternations of silty claystone, clayey siltstone, and siltstone. Unit V (415.58-528.51 m CSF-A) is volcaniclastic-rich sediment composed of silty claystone alternating with tuff. Unit VI (528.51-537.81 $\mathrm{m}$ CSF-A) consists of pelagic claystone. Unit VII (537.81 m CSF-A to the bottom) is the Kashinosaki Knoll basement and is mainly composed of basalt. Each microfossil sample was collected from undisturbed hemipelagic sediment from Unit I to Unit VI.

Sediment samples of 0.5-1.0 g dry weight were disaggregated through the sodium tetraphenylborate method (Hanken, 1979). After the samples became macerated, each was wet-sieved through a $63 \mu \mathrm{m}$ screen. Dried residues were then divided into suitable volumes yielding around 200 planktonic foraminiferal specimens with the use of a sample splitter. Planktonic foraminiferal specimens larger than 125 $\mu \mathrm{m}$ were picked up under a binocular microscope. Scanning electron microphotographs of selected in- dex species were obtained with a JCM-5000 (JEOL Co. Ltd., Japan). To calculate foraminiferal flux (number $/ \mathrm{cm}^{2} / \mathrm{k} . \mathrm{y}$.), we used the onboard data set of dry density and accumulation rate (see the "Site C0012" chapter [Expedition 322 Scientists, 2010]).

The quality of each biohorizon was determined on the basis of the criteria of Hayashi et al. (2013) as follows (Fig. F2):

Quality A = biohorizons recognized by continuous occurrences above their lowest occurrence and below their highest occurrence.

Quality B = biohorizons showing discontinuous occurrence above their lowest occurrence and below their highest occurrence.

Quality C = biohorizons characterized by both rare and sporadic occurrences of the marker taxa.

Taxonomic names in this study generally follow Wade et al. (2011) and Hayashi et al. (2013) except for Paragloborotalia siakensis. This species has previously been regarded as a junior synonym of Paragloborotalia mayeri by many workers (e.g., Bolli and Saunders, 1982). On the basis of scanning electron microphotographs of both holotypes newly redrawn by Zachariasse and Sudijono (2012), we identified all of our specimens as $P$. siakensis rather than $P$. mayeri.

We used the planktonic foraminiferal zonation defined by Berggren et al. (1995) and revised by Wade et al. (2011). The astronomically tuned timetable of planktonic foraminiferal biohorizons in the current timescale (ATNTS2004; Lourens et al., 2004) has been revised in part by Wade et al. (2011). Independent of this, Tian et al. (2008) presented an astronomically tuned timescale over the past $23 \mathrm{Ma}$ at Ocean Drilling Program (ODP) Site 1148 in the South China Sea. We considered both ages for biohorizons of this study.

\section{Results}

With the exception of several barren interval, 72 taxa belonging to 20 genera of planktonic foraminifers were detected at Site C0012 (Table T1). Fossil preservation is generally moderate to poor. In particular, sediment from the lower part of Unit II to the upper part of Unit III has very rare occurrences of planktonic foraminifers with poor preservation and barren intervals (Table T1; Fig. F3). These barren samples contain only thick-walled benthic foraminifers with surfaces disfigured by dissolution. Therefore, the rare occurrences and barren intervals might be the results of dissolution processes beneath the carbonate compensation depth.

A total of 19 biohorizons were recognized in this study (Table T2). During the onboard preliminary 
observation, five biohorizons were reported from CC samples (see the "Site C0012" chapter [Expedition 322 Scientists, 2010]). Among them, the lowest biohorizon, characterized by the first occurrence of Orbulina universa, should be disregarded because our study detected a younger biohorizon marked by the first occurrence of Fohsella peripheroacuta below this horizon. Other four biohorizons $(8,10,14$, and 17 of Table T2) were redefined after examination of section samples in this study.

The last occurrences of Dentoglobigerina altispira altispira (the base of Zone PL5) and Sphaeroidinellopsis seminulina sensu lato (the base of Zone PL4) should be located above Sample 322-C0012A-2R-4, 0.0-8.0 $\mathrm{cm}$ (64.54 m CSF-A). Globorotalia plesiotumida sparsely occur and the last occurrence of this species is estimated to be above Sample 3R-1, 60.0-68.0 cm (70.14 m CSF-A). The last occurrence of Globoturborotalita nepenthes (the base of Zone PL2) is clearly between Samples 3R-1, 60.0-68.0 cm (70.14 m CSF-A), and 4R-1, 50.0-58.0 cm (79.54 m CSF-A). The zonal maker species Globorotalia tumida appears in two samples, with the first occurrence (the base of Zone PL1a) recognized between Samples 4R-1, 50.0-58.0 $\mathrm{cm}$ (79.54 m CSF-A), and 5R-4, 50.0-58.0 cm (93.54 m CSF-A). Only one specimens of Hirsutella margaritae was detected in this study from Sample 10R-5, $60.0-68.0 \mathrm{~cm}$ (137.14 m CSF-A). However, this species was also observed in Samples 4R-CC, 14.0-19.0 $\mathrm{cm}$ (80.79 $\mathrm{m}$ CSF-A), and 7R-CC, $10.0-15.0 \mathrm{~cm}$ (107.95 m CSF-A) during the onboard study (see the "Site C0012" chapter [Expedition 322 Scientists, 2010]). Therefore, the first occurrence of this species is suggested to be below Sample 10R-5, 60.0-68.0 $\mathrm{cm}$. Globorotalia lenguaensis, the zonal marker of the base of Zone M14, was found in Sample 9R-1, 42.0$50.0 \mathrm{~cm}$. Considering the sporadic occurrence of this species reported during the onboard study (see the "Site C0012" chapter [Expedition 322 Scientists, 2010]), the last occurrence of this species is implied to be above Sample 9R-1, 42.0-50.0 cm (121.46 m CSF-A). Globigerinoides conglobatus was recognized from Samples 4R-CC, 14.0-19.0 cm (80.79 m CSF-A), and 6R-CC, $10.5-15.5 \mathrm{~cm}$ (101.845 m CSF-A) during the onboard study (see the "Site C0012" chapter [Expedition 322 Scientists, 2010]). In this study, however, we detected only one individual of this species in Sample 4R-1, 50.0-58.0 cm $(79.54 \mathrm{~m}$ CSF-A). Thus the first occurrence of this species should be located below Sample 6R-CC, 10.5-15.5 $\mathrm{cm}$ (101.845 m CSF-A). The dominant coiling direction of Neogloboquadrina acostaensis switches from sinistral to dextral between Samples 11R-5, 74.0-82.0 $\mathrm{cm}$ (146.78 m CSF-A), and 11R-7, 46.0-54.0 cm (149.50 m CSF-A). The first occurrence of G. plesiotu- mida (the base of Subzone M13b) is placed between Samples 21R-4, 40.0-48.0 cm (239.64 m CSF-A), and 22R-3, 45.0-53.0 cm (247.69 m CSF-A). Globoturborotalita extremus individuals were obtained from three samples, with the first occurrence of this species implied to occur below Sample 16R-4, 70.0-78.0 cm (192.74 m CSF-A). The last occurrence of Globoquadrina dehiscens lies between Samples 24R-4, 52.0$60.0 \mathrm{~cm}(268.26 \mathrm{~m} \mathrm{CSF}-\mathrm{A})$, and 25R-1, 53.0-61.0 cm (273.27 m CSF-A). The first occurrence of $N$. acostaensis (the base of Subzone M13a) may be located below Samples 26R-2, 68.0-76.0 cm (284.42 m CSF-A). However, the precise position of this biohorizon cannot be determined because of the scarce fossil occurrence within it. The last occurrence of $P$. siakensis (the base of Zone M12) is detected between Samples 25R-1, 53.0-61.0 cm (273.27 m CSF-A), and 25R-5, $68.0-76.0 \mathrm{~cm}$ (279.42 m CSF-A). Globoturborotalita decoraperta is characterized by rare and sporadic occurrences and the lowest horizon where it is found is in Sample 26R-2, 68.0-76.0 cm (284.42 m CSF-A). Therefore, the first occurrence of this species could be suggested to be below this sample. The last occurrence of Globigerinoides subquadratus occurs between Samples 27R-3, 38.0-46.0 cm (295.12 m CSF-A), and 28R-3, 65.0-73.0 cm (304.89 m CSF-A). The first occurrence of $G$. nepenthes (the base of Zone M11) may be found below Samples 31R-5, 74.0-82.0 cm (336.48 m CSF-A). However, the position of this biohorizon may be subject to uncertainty because the species shows only sporadic occurrence in the middle Miocene interval at this site. The last occurrence of Fohsella peripheroronda is detected between Samples 36R-3, 80.0-88.0 cm (379.84 m CSF-A), and 37R-1, $35.0-43.0 \mathrm{~cm}$ (385.89 m CSF-A). The lowermost sample at the studied site (Sample 50R-3, 70.0-78.0 cm; $512.74 \mathrm{~m}$ CSF-A) contains $F$. peripheroacuta. Therefore, this sample may be considered younger than the first occurrence of $F$. peripheroacuta (the base of the Zone M7).

At Site C0012, the first occurrence of $N$. acostaensis (the base of Subzone M13a) is located below the last occurrence of $P$. siakensis (the base of Zone M12). Such discrepancy in these two biohorizons has been reported widely in subtropical to temperate regions. For example, the last occurrence of $P$. siakensis also crosses over the first occurrence of $N$. acostaensis at Deep Sea Drilling Project Site 563 in the North Atlantic (Miller et al., 1994) and at IODP Site U1338 in the eastern equatorial Pacific (Hayashi et al., 2013). Wade et al. (2011) suggested that the discrepancy in the Atlantic Ocean may be due to diachrony of the extinction of $P$. siakensis. In the western Pacific, however, our study is the first report of the overlap range of $N$. acostaensis and P. siakensis. Further study is re- 
quired to clarify the reason of the discrepancy in this region.

Figure F3 represents the age-depth plot of Site C0012 using biohorizons of calcareous nannofossils (see the "Site C0012" chapter [Expedition 322 Scientists, 2010]) and planktonic foraminifers (this study). The results indicate that foraminiferal biohorizons of this study generally are consistent with the calcareous nannofossil data. In particular, comparison of the two different timetables reveals that biohorizons of the study by Tian et al. (2008) are more concordant with calcareous nannofossil data than those of the study by Wade et al. (2011) (Fig. F3). This result can be explained by the difference in ecological provinces: Tian et al. (2008) constructed their astronomically tuned timescale by using sites in the South China Sea, approximately $2300 \mathrm{~km}$ southwest of Site C0012, whereas that of Wade et al. (2011) is mainly based on Atlantic sites (ODP Sites 925 and 926) and eastern equatorial Pacific sites (ODP Legs 111 and 138). Among these biohorizons, the last occurrences of $G$. dehiscens and F. peripheroronda have been previously reported as diachronous around the Japanese Islands. Motoyama et al. (2004) mentioned that the age of the last occurrence of $G$. dehiscens was estimated at approximately 8.4-9.6 Ma at ODP Leg 186 in the Sanriku forearc basin in northeastern Japan. The last occurrence of $F$. peripheroronda was numerically determined as 13.0 Ma by biotite K-Ar ages in the Karasuyama area in the central part of the Honshu Island (Hayashi and Takahashi, 2002). The precise understanding of diachronous biohorizons around Japan requires further studies.

\section{Faunal references}

Biorbulina bilobata (d'Orbigny), 1846, p. 164, pl. 9, figs. 1114.

Catapsydrax unicavus Bolli, Loeblich, and Tappan, 1957, p. 37, pl. 7, figs. 9a-9c.

Dentoglobigerina altispira altispira (Cushman and Jarvis), 1936, p. 5, pl. 1, figs. 13a-13c; Pl. P1, fig. 1.

Dentoglobigerina altispira globosa (Bolli), 1957, p. 111, pl. 24 , figs. 9a-10c.

Fohsella peripheroacuta (Blow and Banner), 1966, p. 294, pl. P1, figs. 2a-2c.

Fohsella peripheroronda (Blow and Banner), 1966, p. 294, pl. 1, figs. $1 \mathrm{a}-1 \mathrm{c}$.

Globigerina angustiumbilicata Bolli, 1957, p. 109, pl. 22, figs. 12a-13c.

Globigerina bulloides d'Orbigny, 1826; Banner and Blow, 1960, pl. 1, figs. 1-4.

Globigerina falconensis Blow, 1959, p. 177, pl. 9, figs. 40a40c, 41.

Globigerina praebulloides Blow, 1959, p. 180, pl. 8, figs. 47a47c; pl. 9, fig. 48.
Globigerina pseudociperoensis Blow, 1969, p. 381, pl. 17, figs. $8,9$.

Globigerinella obesa (Bolli), 1957, p. 119, pl. 29, figs. 2a, 3.

Globigerinella siphonifera (d'Orbigny), 1839, p. 83, pl. 4, figs. 15-18; Banner and Blow, 1960, p. 22-23, figs. 2a2c.

Globigerinita glutinata (Egger), 1893, p. 371, pl. 13, figs. 1921.

Globigerinita uvula (Ehrenberg), 1861, pl. 2, figs. 24-25.

Globigerinoides bollii Blow, 1959, p. 189, pl. 10, figs. 65a$65 \mathrm{c}$.

Globigerinoides conglobatus (Brady), 1879, p. 28; Brady, 1884, pl. 80, figs. 1-5.

Globigerinoides immaturus LeRoy, 1939, p. 263, pl. 3, figs. 19-21.

Globigerinoides quadrilobatus (d'Orbigny), 1846, p. 164, pl. 9, figs. 7-10.

Globigerinoides ruber (d'Orbigny), 1839, p. 82, pl. 4, figs. 12-14.

Globigerinoides sacculifer (Brady), 1877, p. 535; Brady, 1884, pl. 80, figs. 11-17.

Globigerinoides subquadratus Brönnimann, 1954, p. 680, pl. 1, figs. 8a-8c; P1. P1, fig. 3

Globigerinoides trilobus (Reuss), 1850, p. 374, pl. 447, figs. 11a-11c.

Globoconella conoidea (Walters), 1965, p. 124, figs. 8i-8m.

Globoconella conomiozea (Kennett), 1966, p. 235, figs. 10a$10 \mathrm{c}$.

Globoconella miozea (Finlay), 1939, p. 326, pl. 29, figs. 159161.

Globoconella sphericomiozea (Walters), 1965, p. 126, figs. 8n-8s.

Globoquadrina baroemoenensis (LeRoy), 1939, p. 263, pl. 6, figs. 1-2.

Globoquadrina dehiscens (Chapman, Parr and Collins), 1934 , p. 569 , pl. 11, figs. 36a-36c; Pl. P1, fig. 5.

Globoquadrina venezuelana (Hedberg), 1937, p. 681, pl. 92, fig. $72 \mathrm{~b}$.

Globorotalia adamantae Saito, 1963, p. 173, pl. 54, figs. 4a$5 \mathrm{c}$.

Globorotalia bykovae (Aisenstat), in Subbotina et al. (1960), p. 69 , pl. 13, figs. $7 \mathrm{a}-8 \mathrm{~b}$.

Globorotalia iwaiensis Takayanagi and Oda, in Takayanagi et al. (1976), p. 376, pl. 1, figs. 2a-2c, 3a-3c.

Globorotalia lenguaensis Bolli, 1957, p. 120, pl. 29, figs. 5a$5 \mathrm{c}$.

Globorotalia plesiotumida Blow and Banner, 1965, p. 1353, figs. $2 \mathrm{a}-2 \mathrm{c}$.

Globorotalia pseudomiocenica Bolli and Bermúdez, 1965, p. 140, pl. 1, figs. 13-15.

Globorotalia rikuchuensis Takayanagi and Oda, in Takayanagi et al. (1976), p. 372, pl. 1, figs. 4a-4d, 5a-5c.

Globorotalia tumida (Brady), 1877, p. 535; Brady, 1884, pl. 103, figs. 4-6.; Pl. P1, figs. 4a-4c.

Globoturborotalita decoraperta (Takayanagi and Saito), 1962, p. 85 , pl. 28 , figs. 10 a-10c.

Globoturborotalita druryi (Akers), 1955, p. 654, pl. 65, fig. 1.

Globoturborotalita extremus (Bolli and Bermúdez), 1965, p. 139 , pl. 1, figs. 10-12.

Globoturborotalita nepenthes (Todd), 1957, p. 301, figs. 7a7b; Pl. P1, fig. 6. 
Globoturborotalita obliquus (Bolli), 1957, p. 113, pl. 25, figs. 10a-10c.

Globoturborotalita woodi (Jenkins), 1960, p. 352, pl. 2, figs. $2 \mathrm{a}-2 \mathrm{c}$

Hirsutella margaritae (Bolli and Bermúdez), 1965, p. 139, pl. 1, figs. 16-18; Bolli and Bermúdez, 1978, p. 138, pl. 1, figs. 1-9.

Hirsutella praemargaritae (Catalano and Sprovieri), 1969, p. 523 , pl. 1 , figs. $5 \mathrm{a}-5 \mathrm{c}$.

Hirsutella praescitula (Blow), 1959, p. 221, pl. 19, figs. 128a$128 \mathrm{c}$.

Hirsutella scitula (Brady), 1882, p. 716; Banner and Blow, 1960, pt. 1, p. 27, pl. 5, fig. 5.

Menardella archeomenardii (Bolli), 1957, p. 119, pl. 28, figs. 11a-11c.

Menardella menardii (Parker, Jones and Brady), 1865, Pt. XII

Menardella praemenardii (Cushman and Stainforth), 1945, p. 70, pl. 13, figs. $14 \mathrm{a}-14 \mathrm{c}$.

Neogloboquadrina acostaensis (Blow), 1959, p. 208, pl. 17, figs. 106a-106c; Pl. P1, figs. 7a-7b.

Neogloboquadrina conglomerata (Schwager), 1866, p. 255, pl. 7, fig. 113; Banner and Blow, 1960, p. 7, pl. 2, fig. 3.

Neogloboquadrina continuosa (Blow), 1959, p. 218, pl. 19, figs. $125 \mathrm{a}-125 \mathrm{c}$.

Neogloboquadrina dutertrei (d'Orbigny), 1839, p. 84, pl. 4, figs. 19-21; Banner and Blow, 1960, pt. 1, pl. 2, fig. 1.

Neogloboquadrina humerosa (Takayanagi and Saito), 1962, p. 78 , figs. $1 \mathrm{a}-2 \mathrm{~b}$.

Neogloboquadrina incompta (Cifelli), 1961, p. 83, pl. 4, figs. $1-7$.

Neogloboquadrina kagaensis (Maiya, Saito and Sato), 1976, p. 409 , pl. 3, figs. $4 a-4 b, 5,6 a-6 c$.

Neogloboquadrina pachyderma (Ehrenberg), 1861, p. 276; Banner and Blow, 1960, pt. 1, p. 4, pl. 3. figs. 4a-4c.

Neogloboquadrina praeatlantica Foresi, Iaccarino and Salvatorini, 2002, p. 327, pl. 1, figs. 1-13; pl. 2, figs 1-12.

Neogloboquadrina praehumerosa (Natori), 1976, p. 232, pl. 2, figs. $1 \mathrm{a}-1 \mathrm{c}, 3 \mathrm{a}-3 \mathrm{c}$.

Neogloboquadrina pseudopachyderma (Cita, Premoli-Silva and Rossi), 1965, p. 233, pl. 20, figs. 3a-3c, 4a-3c, 6; pl. 31 , figs. $6 a-6 c$.

Orbulina suturalis Brönnimann, 1951, pt. 4, p. 135, Text fig. IV, figs. 15, 16, 20.

Orbulina universa d'Orbigny, 1839, p. 3, pl. 1, fig. 1.

Paragloborotalia siakensis (LeRoy), 1939, p. 262, pl. 4, figs. 20-22; Pl. P1, figs. 8a-8b; holotype redrawn by Zachariasse and Sudijono, 2012, p. 161, fig. 5.

Pulleniatina primalis Banner and Blow, 1967, p. 142, pl. 1, figs. $2 \mathrm{a}-2 \mathrm{c}$.

Sphaeroidinellopsis disjuncta Finlay, 1940, p. 467, pl. 67, figs. 224-228.

Sphaeroidinellopsis seminulina (Schwager), 1866, p. 256, pl. 7, fig. 112; Pl. P1, figs. 9a-9b.

Sphaeroidinellopsis subdehiscens (Blow), 1959, p. 195, pl. 12, figs. 71a-72; Banner and Blow, 1960, p. 15, figs. 5a-5c.

Tenuitella clemenciae (Bermúdez), 1961, p. 1321, pl. 17, fig. 10.

Tenuitella minutissima (Bolli), 1957, p. 119, pl. 29, fig. 1.

Turborotalita quinqueloba (Natland), 1938, p. 149, pl. 6, figs. 7a-7c.

\section{Acknowledgments}

This research used samples provided by the Integrated Ocean Drilling Program (IODP). We would like to express our appreciation to members of the NanTroSEIZE project for their valuable discussions and helpful encouragements. This study was funded by Grants-in-Aid 23740377 from the Japan Society for the Promotion of Science. Figure F1 was produced by GMT software developed by Wessel and Smith (1991).

\section{References}

Akers, W.H., 1955. Some planktonic foraminifera of the American Gulf Coast and suggested correlations with the Caribbean Tertiary. J. Paleontol., 29(4):647-664. http://www.jstor.org/stable/1300351

Ashi, J., Lallemant, S., Masago, H., and the Expedition 315 Scientists, 2009. Expedition 315 summary. In Kinoshita, M., Tobin, H., Ashi, J., Kimura, G., Lallemant, S., Screaton, E.J., Curewitz, D., Masago, H., Moe, K.T., and the Expedition 314/315/316 Scientists, Proc. IODP, 314/315/ 316: Washington, DC (Integrated Ocean Drilling Program Management International, Inc.). doi:10.2204/ iodp.proc.314315316.121.2009

Banner, F.T., and Blow, W.H., 1960. Some primary types of species belonging to the superfamily Globigerinaceae. Contrib. Cushman Found. Foraminiferal Res., 11(1):1-41.

Banner, F.T., and Blow, W.H., 1967. The origin, evolution and taxonomy of the foraminiferal genus Pulleniatina Cushman, 1927. Micropaleontology, 13(2):133-162. doi:10.2307/1484667

Berggren, W.A, Hilgen, F.J., Langereis, C.G., Kent, D.V., Obradovich, J.D., Raffi, I., Raymo, M.E., and Shackelton, N.J., 1995. Late Neogene chronology: new perspectives in high-resolution stratigraphy. Geol. Soc. Am. Bull., 107(11):1272-1287. doi:10.1130/00167606(1995)107<1272:LNCNPI>2.3.CO;2

Bermúdez, P.J., 1961. Contribución al estudio de las Globigerinidae de la región Caribe-Antillana (Paleoceno-Reciente). Mem. Tercer Congr. Geol. Venezolano, 3:119-393.

Blow, W.H., 1959. Age, correlation, and biostratigraphy of the upper Tocuyo (San Lorenzo) and Pozón Formations, eastern Falcón, Venezuela. Bull. Am. Paleontol., 39(178):67-251.

Blow, W.H., 1969. Late middle Eocene to Recent planktonic foraminiferal biostratigraphy. Proc. Int. Conf. Planktonic Microfossils, 1:199-422.

Blow, W.H., and Banner, F.T., 1965. Two new taxa of the Globorotaliidae (Globigerinacea, Foraminifera) assisting determination of the late Miocene/early Miocene boundary. Nature, 207:1353.

Blow, W.H., and Banner, F.T., 1966. The morphology, taxonomy and biostratigraphy of Globorotalia barisanensis LeRoy, Globorotalia fohsi Cushman and Ellisor, and related taxa. Micropaleontology, 12(3):286-302. doi:10.2307/1484548 
Bolli, H.M., 1957. Planktonic foraminifera from the Oligocene-Miocene Cipero and Lengua formations of Trinidad, B.W.I. In Loeblich, A.R., Jr., Tappan, H., Beckmann, J.P., Bolli, H.M., Gallitelli, E.M., and Troelsen, J.C. (Eds.), Studies in Foraminifera. Bull.-U.S. Natl. Mus., 215:97123.

Bolli, H.M., and Bermúdez, P.J., 1965. Zonation based on planktonic foraminifera of middle Miocene to Pliocene warm-water sediments. Asoc. Venezolana Geol. Miner. Petrol., Bol. Inf., 8(5):121-149.

Bolli, H.M., and Bermúdez, P.J., 1978. A neotype for Globorotalia margaritae Bolli and Bermúdez. J. Foraminiferal Res., 8(2):138-142. doi:10.2113/gsjfr.8.2.138

Bolli, H.M., Loeblich, A.R., Jr., and Tappan, H., 1957. Planktonic foraminiferal families Hantkeninidae, Orbulinidae, Globorotaliidae, and Globotruncanidae. Bull.U.S. Nat. Mus., 215:3-50.

Bolli, H.M., and Saunders, J.B., 1982. Globorotalia mayeri and its relationship to Globorotalia siakensis and Globorotalia continuosa. J. Foraminiferal Res., 12(1):39-50. doi:10.2113/gsjfr.12.1.39

Brady, H.B., 1877. Supplementary note on the foraminifera of the Chalk (?) of the New Britain Group. Geol. Mag., 4:534-546. doi:10.1017/S0016756800150137

Brady, H.B., 1879. Notes on some of the reticularean Rhizopoda (Foraminifera and Polycystina) of the NorthPolar Expedition of 1875-76. Ann. Mag. Nat. Hist., 5:425-452.

Brady, H.B., 1882. Report on the Foraminifera. In Tizard, L., and Murray, J. (Eds.), Exploration of the Faröe Channel During the Summer of 1880, in Her Majesty's Ship Knight Errant, with Subsidiary Reports. Proc. R. Soc. Edinburgh, 11:708-717.

Brady, H.B., 1884. Report on the Foraminifera dredged by H.M.S. Challenger, during the years 1873-1876. Rep. Sci. Results Challenger Exped., Zool., 9:1-814.

Brönnimann, P., 1951. The genus Orbulina d'Orbigny in the Oligo-Miocene of Trinidad, B.W.I. Contrib. Cushman Found. Foraminiferal Res., 2(4):132-138.

Brönniman, P., 1954. Appendix: Descriptions of new species. In Todd, R., Cloud, P.E., Jr., Low, D., and Schmidt, R.G. (Eds.), Probable Occurrence of Oligocene in Saipan. Am. J. Sci., 252:680.

Catalano, R., and Sprovieri, R., 1969. Stratigrafia e micropaleontologia dell'intervallo tripolaceo di torrente Rossi, Enna. Atti dell'Accad. Gio. di Sci. Nat., 7(1):513527.

Chapman, F., Parr, W.J., and Collins, A.C., 1934. Tertiary foraminifera of Victoria, Australia: the Balcombian deposits of Port Philip (Pt. III). J. Linn. Soc. London, Zool., 38(262):553-577.doi:10.1111/j.10963642.1934.tb00996.x

Cifelli, R., 1961. Globigerina incompta, a new species of pelagic foraminifera from the North Atlantic. Contrib. Cushman Found. Foraminiferal Res., 12(3):83-86.

Cita, M.B., Premoli-Silva, I., and Rossi, R., 1965. Foraminiferi planctonici del Tortoniano-tipo. Riv. Ital. Paleont., 71(1): 217-308.
Cushman, J.A., and Jarvis, P.W., 1936. Three new Foraminifera from the Miocene Bowden Marl of Jamaica. Contrib. Cushman Lab. Foraminiferal Res., 12:3-5.

Cushman, J.A., and Stainforth, R.M., 1945. The foraminifera of the Cipero Marl Formation of Trinidad, British West Indies. Spec. Publ._Cushman Lab. Foraminiferal Res., 14:1-75.

d'Orbigny, A., 1846. Foraminiferes Fossiles du Bassin Tertiaire de Vienne (Autriche): Paris (Gide et Comp.) http:// gallica.bnf.fr/ark:/12148/bpt6k97267b

d'Orbigny, A.D., 1826. Tableau méthodique de la classe des céphalopodes. Ann. Sci. Nat., Paris, Ser. 1, 7:245-314.

d'Orbigny, A.D., 1839. Foraminifères. In de la Sagra, R. (Ed.), Histoire Physique, Politique et Naturelle de Lîle de Cuba: Paris (Arthus Bertrand), 8:1-224

Egger, J.G., 1893. Foraminiferen aus Meeresgrundproben, gelothet von 1874 bis 1876 von S. M. Sch. Gazelle. Abh. Bayer. Akad. Wiss., Math.-Physik. Kl., 18:193-458.

Ehrenberg, C.G., 1861. Elemente des tiefen Meeresgrundes in Mexikanischen Golfstrome bei Florida; Ueber die Tiefgrund-Verhältnisse des Oceans am Eingang der Davisstrasse und bei Island. K. Preuss. Akad. Wiss. Berlin, Monatsber., 222-240, 275-315.

Expedition 322 Scientists, 2010. Site C0012. In Saito, S., Underwood, M.B., Kubo, Y., and the Expedition 322 Scientists, Proc. IODP, 322: Tokyo (Integrated Ocean Drilling Program Management International, Inc.). doi:10.2204/iodp.proc.322.104.2010

Finlay, H.J., 1939. New Zealand foraminifera: key species in stratigraphy, No. 3. Trans. R. Soc. N.Z., 69:309-329.

Finlay, H.J., 1940. New Zealand Foraminifera: key species in stratigraphy, No. 4. Trans. R. Soc. N.Z., 69:448-472.

Foresi, L.M., Iaccarino, S.M., and Salvatorini, G., 2002. Neogloboquadrina atlantica praeatlantica, new subspecies from late Middle Miocene. Riv. Ital. Paleontol. Stratigr., 108(2):325-336.

Hanken, N.-M., 1979. The use of sodium tetraphenylborate and sodium chloride in the extraction of fossils from shales. J. Paleontol., 53(3):738-741. http:// www.jstor.org/stable/1304012

Hayashi, H., Asano, S., Yamashita, Y., Tanaka, T., and Nishi, H., 2011. Data report: late Neogene planktonic foraminiferal biostratigraphy of the Nankai Trough, IODP Expedition 315. In Kinoshita, M., Tobin, H., Ashi, J., Kimura, G., Lallemant, S., Screaton, E.J., Curewitz, D., Masago, H., Moe, K.T., and the Expedition 314/315/316 Scientists, Proc. IODP, 314/315/316: Washington, DC (Integrated Ocean Drilling Program Management International, Inc.). doi:10.2204/ iodp.proc.314315316.206.2011

Hayashi, H., Idemitsu, K., Wade, B.S., Idehara, Y., Kimoto, K., Nishi, H., and Matsui, H., 2013. Middle Miocene to Pleistocene planktonic foraminiferal biostratigraphy in the eastern equatorial Pacific Ocean. Paleontol. Res., 17(1):91-109. doi:10.2517/1342-8144-17.1.91

Hayashi, H., and Takahashi, M., 2002. Planktonic foraminiferal biostratigraphy of the Miocene Arakawa Group in central Japan. Rev. Mexi. Cien. Geol., 19(3):190-205. http://www.redalyc.org/pdf/572/57219306.pdf 
Hedberg, H.D., 1937. Foraminifera of the middle Tertiary Carapita Formation of northeastern Venezuela. J. Paleontol., 11(8):661-697.http://www.jstor.org/stable/ 1298440

Jenkins, D.G., 1960. Planktonic foraminifera from the Lakes Entrance oil shaft, Victoria, Australia. Micropaleontology, 6(4):345-371. doi:10.2307/1484217

Kennett, J.P., 1966. The Globorotalia crassaformis bioseries in north Westland, and Marlborough, New Zealand. Micropaleontology, 12(2): 235-245. doi:10.2307/ 1484711

LeRoy, L.W., 1939. Some small foraminifera, ostracoda and otoliths from the Neogene ("Miocene") of the RokanTapanoeli area, Central Sumatra. Natuurk. Tijdschr. Nederl. Indie, 99(6):214-296.

Lourens, L.J., Hilgen, F.J., Laskar, J., Shackleton, N.J., and Wilson, D., 2004. The Neogene period. In Gradstein, F.M., Ogg, J., et al. (Eds.), A Geologic Time Scale 2004: Cambridge, UK (Cambridge Univ. Press), 409-440. doi:10.1017/CBO9780511536045.022

Maiya, S., Saito, T., and Sato, T., 1976. Late Cenozoic planktonic foraminiferal biostratigraphy of Northwest Pacific sedimentary sequences. In Takayanagi, Y., and Saito, T. (Eds.), Progress in Micropaleontology: New York (Micropaleontology Press), 395-422.

Miller, K.G., Wright, J.D., Van Fossen, M.C., and Kent, D.V., 1994. Miocene stable isotopic stratigraphy and magnetostratigraphy of Buff Bay, Jamaica. Geol. Soc. Am. Bull., 106(12):1605-1620. doi:10.1130/ 0016-7606(1994)106<1605:MSISAM>2.3.CO;2

Motoyama, I., Niitsuma, N., Maruyama, T., Hayashi, H., Kamikuri, S., Shiono, M., Kanamatsu, T., Aoki, K., Morishita, C., Hagino, K., Nishi, H., and Oda, M., 2004. Middle Miocene to Pleistocene magneto-biostratigraphy of ODP Sites 1150 and 1151, northwest Pacific: sedimentation rate and updated regional geological timescale. Isl. Arc, 13(1):289-305. doi:10.1111/j.14401738.2003.00426. $\mathrm{x}$

Natland, M.L., 1938. New species of Foraminifera from off the West Coast of North America and from the later Tertiary of the Los Angeles basin. Bull. Scripps Inst. Oceanogr., 4(5):137-163.

Natori, H., 1976. Planktonic foraminiferal biostratigraphy and datum planes in the late Cenozoic sedimentary sequence in Okinawa-jima, Japan. Progress in Micropaleontology: New York (Micropaleontology Press), 214-243.

Parker, W.K., Jones, T.R., and Brady, H.B., 1865. On the nomenclature of the foraminifera, Part XII. The species enumerated by d'Orbigny in the "Annales des Sciences Naturelles, vol. 7, 1826." Ann. Mag. Nat. Hist., Ser. 3, 16:15-41.

Reuss, A.E., 1850. Neue Foraminiferen aus den Schichten des Oesterreichischen Tertiärbeckens. Sitzaber. K. Akad. Wiss., Wien, Math.-Naturw., Kl., Denkschrift, 1(1):365390.
Saito, T., 1963. Miocene planktonic foraminifera from Honshu, Japan. Sci. Rep. Tohoko Univ., Ser. 2, 35:123-209.

Schwager, C., 1866. Fossile Foraminiferen von Kar Nikobar. Novara Expedition, 1857-1859, Wein, Geol. Theil, 2:187268.

Subbotina, N.N., Pishvanova, L.S., and Ivanova, L.V., 1960. Stratigrafiya oligotsenovikh i miotsenovikh otlozheniy Predkarpatya po foraminiferam. Mikrofauna SSSR, 11, Trudi VNIGRI, 153:5-127.

Takayanagi, Y., and Saito, T., 1962. Planktonic foraminifera from the Nobori Formation, Shikoku, Japan. Sci. Rep. Tohoku Univ., Ser. 2, 5:647-706.

Takayanagi, Y., Takayama, T., Sakai, T., Oda, M., and Kitazato, H., 1976. Microbiostratigraphy of some middle Miocene sequences in northern Japan. In Takayanagi, Y., and Saito, T. (Eds.), Progress in Micropaleontology: Selected Papers in Honor of Prof. Kiyoshi Asano: New York (Micropaleontol. Press), 356-381.

Tian, J., Zhao, Q., Wang, P., Li, Q., and Cheng, X., 2008. Astronomically modulated Neogene sediment records from the South China Sea. Paleoceanography, 23(3):PA3210. doi:10.1029/2007PA001552

Todd, R., 1957. Smaller foraminifera. In Geology of Saipan, Mariana Islands (Pt. 3), Paleontology. U.S. Geol. Surv. Prof. Pap., 280-H:265-320.

Underwood, M.B., Saito, S., Kubo, Y., and the Expedition 322 Scientists, 2010. Expedition 322 summary. In Saito, S., Underwood, M.B., Kubo, Y., and the Expedition 322 Scientists, Proc. IODP, 322: Tokyo (Integrated Ocean Drilling Program Management International, Inc.). doi:10.2204/iodp.proc.322.101.2010

Wade, B.S., Pearson, P.N., Berggren, W.A., and Pälike, H., 2011. Review and revision of Cenozoic tropical planktonic foraminiferal biostratigraphy and calibration to the geomagnetic polarity and astronomical time scale. Earth-Sci. Rev., 104(1-3):111-142. doi:10.1016/j.earscirev.2010.09.003

Walters, R., 1965. The Globorotalia zealandica and G. miozea lineages. N. Z. J. Geol. Geophys., 8(1):109-127. doi:10.1080/00288306.1965.10422135

Wessel, P., and Smith, W.H.F., 1991. Free software helps map and display data. Eos, Trans. Am. Geophys. Union, 72(41):441. doi:10.1029/90EO00319

Zachariasse, W.J., and Sudijono, 2012. New data on the morphology and classification of the Oligocene-Miocene planktonic foraminifera Paragloborotalia siakensis (LeRoy, 1939). J. Foraminiferal Res., 42(2):156-168. doi:10.2113/gsjfr.42.2.156

Initial receipt: 6 June 2012

Acceptance: 22 September 2014

Publication: 12 December 2014

MS 322-206 
Figure F1. Map showing Site C0012 with previous Deep Sea Drilling Project, Ocean Drilling Program, and Integrated Ocean Drilling Program sites in and around Nankai Trough in the northwestern Pacific Ocean.

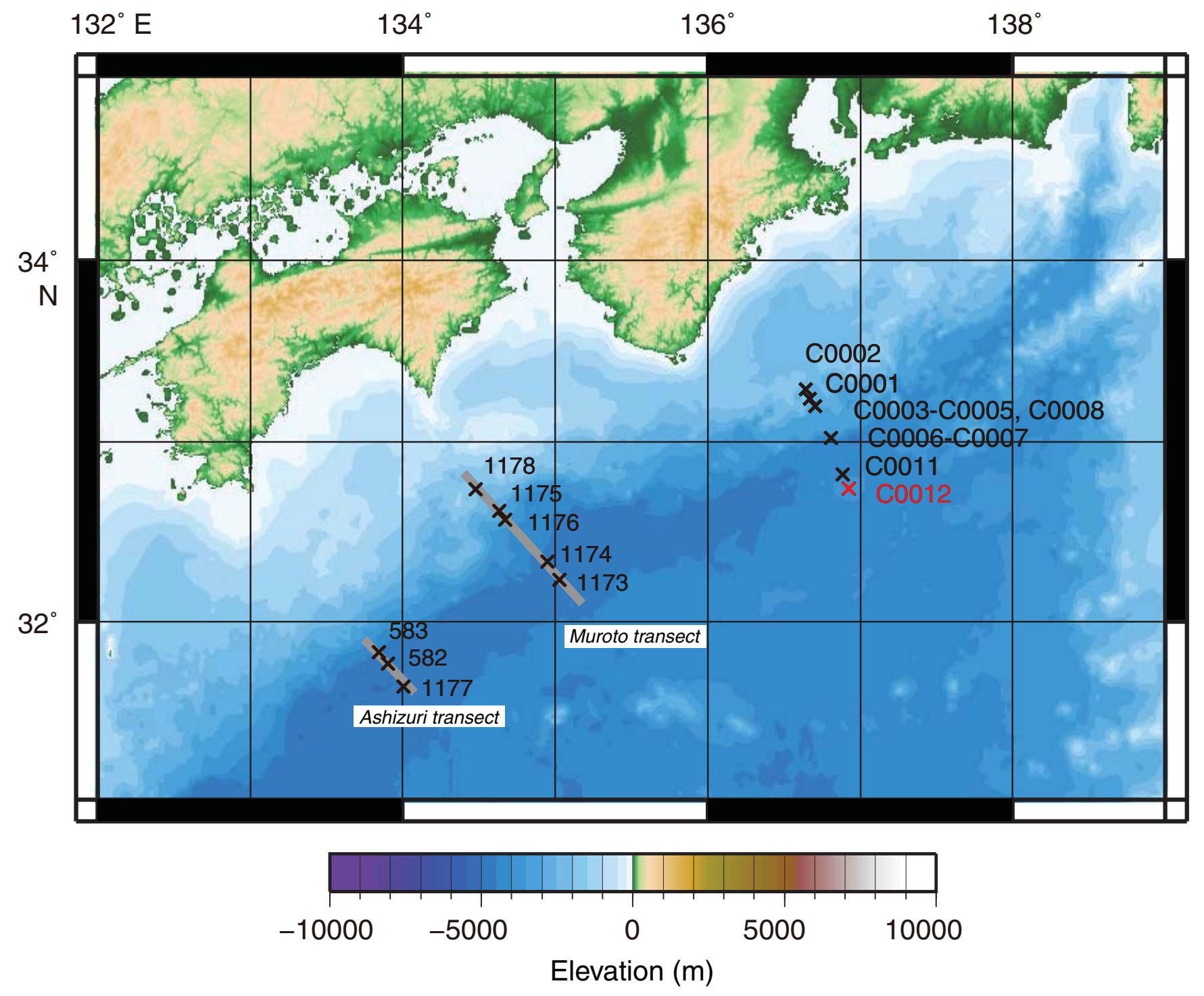


Figure F2. Schematic illustration of quality criterion (A-C) of biohorizons (partly modified after Hayashi et al., 2013). $\mathrm{LO}=$ last occurrence, $\mathrm{FO}=$ first occurrence.

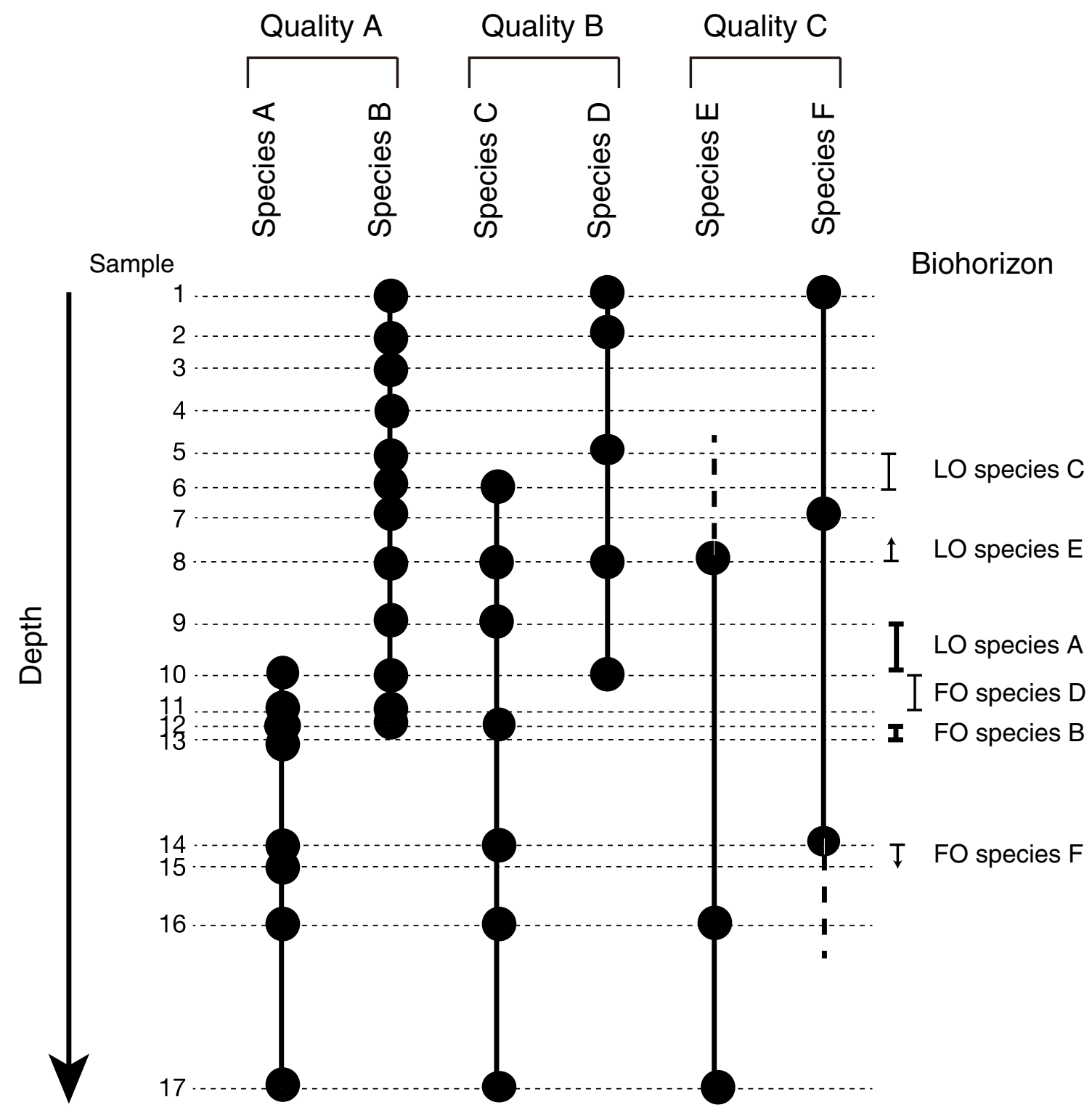


Figure F3. Age-depth plot for Site C0012 and depth plots of planktonic foraminiferal (PF) flux, benthic foraminiferal (BF) flux, and planktonic/total foraminiferal $(\mathrm{P} / \mathrm{T})$ ratio. Planktonic foraminiferal biohorizons are plotted on the basis of Wade et al. (2011) and Tian et al. (2008) timescales. Nannofossil data are quoted from the onboard data (see the "Site C0012" chapter [Expedition 322 Scientists, 2010]). Biohorizon numbers are defined in Table T2.

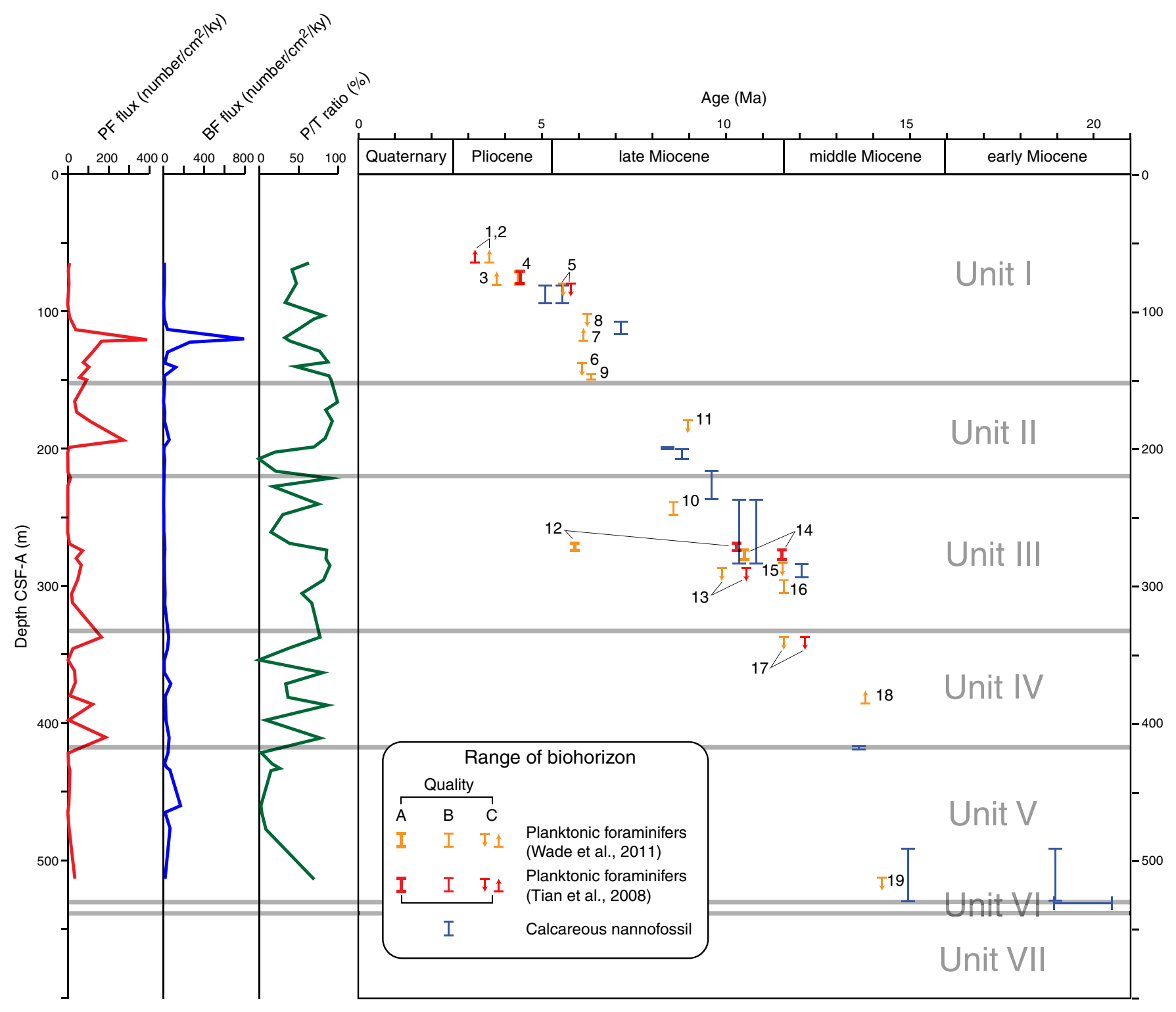


Table T1. Stratigraphic distribution of planktonic foraminiferal species, Hole C0012A. This table is available in an oversized format.

Table T2. Planktonic foraminiferal biohorizons including depth range, mean depth, and samples containing biohorizons, Hole C0012A.

\begin{tabular}{|c|c|c|c|c|c|c|c|c|c|}
\hline $\begin{array}{c}\text { Event } \\
\text { (base of zone) }\end{array}$ & $\begin{array}{c}\text { Age } \\
\text { BW11 } \\
(\mathrm{Ma})\end{array}$ & $\begin{array}{l}\text { Age } \\
\text { TJ08 } \\
(\mathrm{Ma})\end{array}$ & $\begin{array}{l}\text { Top, core, section, } \\
\text { interval }(\mathrm{cm})\end{array}$ & $\begin{array}{l}\text { Depth } \\
\text { CSF-A (m) }\end{array}$ & $\begin{array}{l}\text { Bottom, core, } \\
\text { section, } \\
\text { interval }(\mathrm{cm})\end{array}$ & $\begin{array}{c}\text { Bottom } \\
\text { depth } \\
\text { CSF-A (m) }\end{array}$ & $\begin{array}{c}\text { Mean } \\
\text { depth } \\
\text { CSF-A }(\mathrm{m})\end{array}$ & $\begin{array}{l}\text { Range } \\
( \pm \mathrm{m})\end{array}$ & Quality \\
\hline & & & $322-\mathrm{C} 0012 \mathrm{~A}-$ & & $322-\mathrm{C} 0012 \mathrm{~A}-$ & & & & \\
\hline LO Dentoglobigerina altispira altispira (PL5) & 3.47 & 3.18 & - & - & $2 \mathrm{R}-4,0.0-8.0$ & 64.54 & 64.54 & - & C \\
\hline LO Sphaeroidinellopsis seminulina sensu lato (PL4) & 3.59 & & - & - & $2 \mathrm{R}-4,0.0-8.0$ & 64.54 & 64.54 & - & C \\
\hline LO Globorotalia plesiotumida & 3.77 & & - & - & $3 R-1,60.0-68.0$ & 70.14 & 70.14 & - & C \\
\hline LO Globoturborotalita nepenthes (PL2) & 4.37 & 4.43 & $3 R-1,60.0-68.0$ & 70.14 & $4 R-1,50.0-58.0$ & 79.54 & 74.84 & 4.70 & A \\
\hline FO Globorotalia tumida (PL1a) & 5.57 & 5.77 & $4 \mathrm{R}-1,50.0-58.0$ & 79.54 & - & - & 79.54 & - & C \\
\hline FO Hirsutella margaritae & 6.08 & & $10 \mathrm{R}-5,60.0-68.0$ & 137.14 & - & - & 137.14 & - & C \\
\hline LO Globorotalia lenguaensis (M14) & 6.13 & & - & - & $9 \mathrm{R}-1,42.0-50.0$ & 121.46 & 121.46 & - & C \\
\hline FO Globigerinoides conglobatus & 6.20 & & 6R-CC, 10.5-15.5 & 101.85 & - & - & 101.85 & - & C \\
\hline StoD Neogloboquadrina acostaensis & 6.34 & & $11 \mathrm{R}-5,74.0-82.0$ & 146.78 & $11 \mathrm{R}-7,46.0-54.0$ & 149.50 & 148.14 & 1.36 & B \\
\hline FO Globorotalia plesiotumida (M13b) & 8.58 & & $21 \mathrm{R}-4,40.0-48.0$ & 239.64 & $22 \mathrm{R}-3,45.0-53.0$ & 247.60 & 243.62 & 3.98 & B \\
\hline FO Globoturborotalita extremus & 8.93 & & - & - & $16 \mathrm{R}-4,70.0-78.0$ & 192.74 & 192.74 & - & C \\
\hline LO Globoquadrina dehiscens & 5.92 & 10.26 & $24 \mathrm{R}-4,52.0-60.0$ & 268.26 & $25 \mathrm{R}-1.53 .0-61.0$ & 273.27 & 270.77 & 2.51 & A \\
\hline FO Neogloboquadrina acostaensis (M13a) & 9.83 & 10.50 & $26 \mathrm{R}-2,68.0-76.0$ & 284.42 & - & - & 284.42 & - & C \\
\hline LO Paragloborotalia siakensis (M12) & 10.46 & 11.50 & $25 \mathrm{R}-1,53.0-61.0$ & 273.27 & $25 \mathrm{R}-5,68.0-76.0$ & 279.42 & 276.35 & 3.08 & A \\
\hline FO Globoturborotalita decoraperta & 11.49 & & $26 \mathrm{R}-2,68.0-76.0$ & 284.42 & - & - & 284.42 & - & C \\
\hline LO Globigerinoides subquadratus & 11.54 & & $27 R-3,38.0-46.0$ & 295.12 & $28 \mathrm{R}-3,65.0-73.0$ & 300.01 & 297.57 & 2.44 & B \\
\hline FO Globoturborotalita nepenthes (M11) & 11.63 & 12.13 & $31 \mathrm{R}-5,74.0-82.0$ & 336.48 & - & - & 336.48 & - & C \\
\hline LO Fohsella peripheroronda & 13.80 & & - & - & $37 \mathrm{R}-1,35.0-43.0$ & 385.89 & 385.89 & - & C \\
\hline FO Fohsella peripheroacuta (M7) & 14.24 & & $50 \mathrm{R}-3,70.0-78.0$ & 512.74 & - & - & 512.74 & - & C \\
\hline
\end{tabular}

BW11 = Wade et al. (2011), TJ08 = Tian et al. (2008). FO = first occurrence, LO = last occurrence, StoD = coiling direction change from sinistral to dextral. 
Plate P1. 1. Dentoglobigerina altispira altispira (Cushman and Jarvis); Sample 322-C0012A-2R-4, 0.0-8.0 cm. 2a2c. Fohsella peripheroacuta (Blow and Banner); Sample 41R-6, 12.0-20.0 cm. 3. Globigerinoides subquadratus Brönnimann; Sample 28R-3, 65.0-73.0 cm. 4a-4c. Globorotalia tumida (Brady); Sample 2R-4, 0.0-8.0 cm. 5. Globoquadrina dehiscens (Chapman, Parr and Collins); Sample 44R-3, 92.0-100.0 cm. 6. Globoturborotalita nepenthes (Todd); Sample 7R-3, 60.0-68.0 cm. 7a-7b. Neogloboquadrina acostaensis (Blow); Sample 10R-6, 60.0-68.0 cm. 8a-8b. Paragloborotalia siakensis (LeRoy); Sample 31R-5, 74.0-82.0 cm. 9a-9b. Sphaeroidinellopsis seminulina (Schwager); Sample 4R-1, 50.0-58.0 cm. Scale bars = $100 \mu \mathrm{m}$.

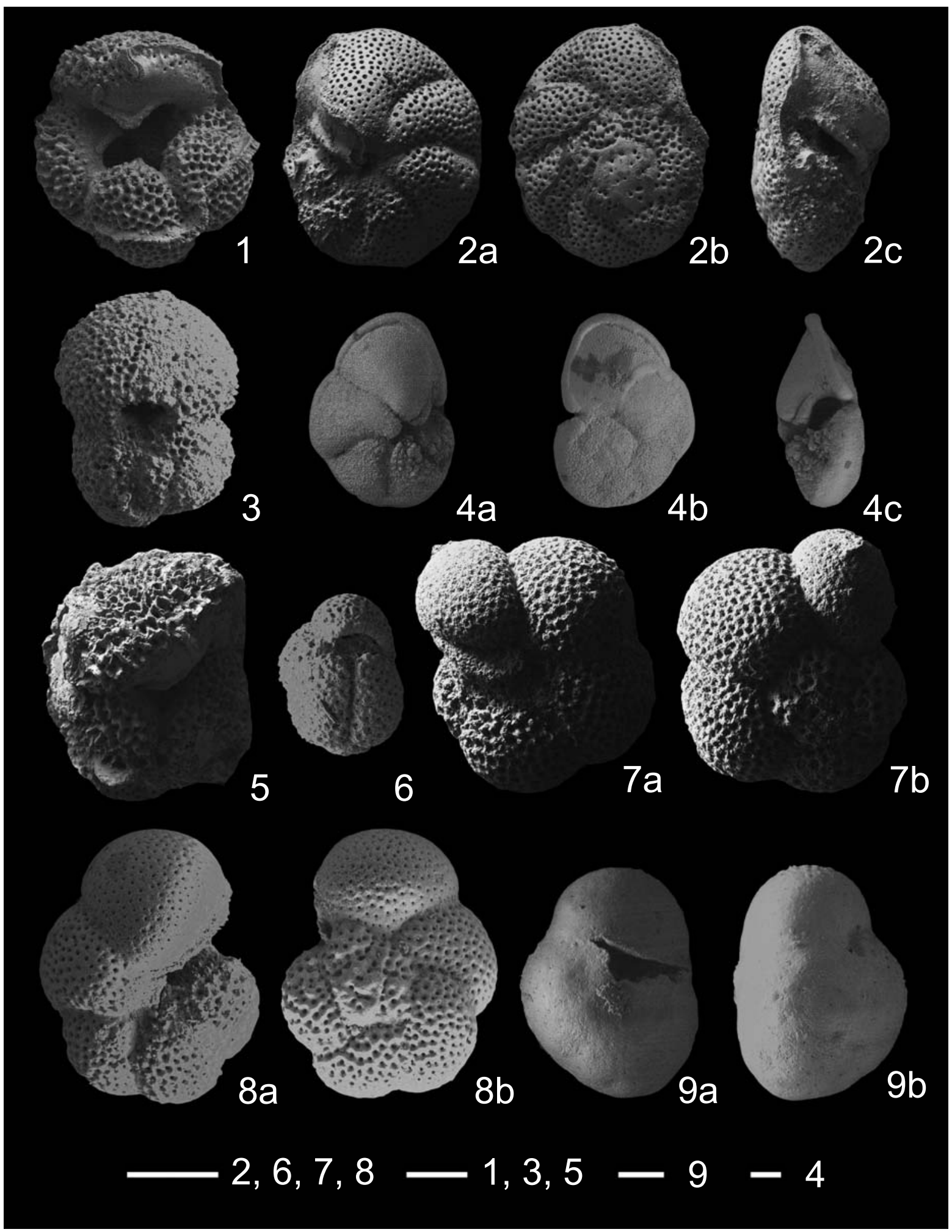

